\title{
Ovarian Steroid Cell Tumor
}

National Cancer Institute

\section{Source}

National Cancer Institute. Ovarian Steroid Cell Tumor. NCI Thesaurus. Code C4215.

An ovarian tumor in which the vast majority of the cells (more than $90 \%$ of the tumor

cells) resemble steroid hormone-secreting cells. It usually presents with androgenic

manifestations. Approximately one-third of the cases follow a malignant clinical course. 